\title{
El Niño Southern Oscillation (1896 to 2016): Quantifying Effects on Winter Precipitation and Temperature in Southwest Ohio, USA
}

ROBERT W. RITZI JR ${ }^{1}$ and LAUREN M. ROBERSON, Department of Earth and Environmental Sciences, Wright State University, Dayton, OH, USA; MICHAEL BOTTOMLEY, Statistical Consulting Center, Wright State University, Dayton, OH, USA.

ABSTRACT. Continental-scale studies of North America suggest that the El Niño Southern Oscillation (ENSO) can cause winters to be warmer, with less precipitation, during El Niño conditions and colder, with more precipitation, during La Niña conditions in the Midwest United States. Two sources of historical records of precipitation and temperature in southwest Ohio from 1896 to 2016 were analyzed. Three statistical methodologies were used to test the hypothesis that anomalies in winter temperature and precipitation occurred in relation to ENSO phases. Eighty percent of EI Niño winters had below-average winter precipitation; the average anomaly was $-5 \mathrm{~cm}$. Precipitation decreased with increase in El Niño strength as measured by the Multivariate ENSO Index (MEI). These results were statistically significant beyond the $95 \%$ level. However, variation in MEI only accounted for $3 \%$ of the overall variability in winter precipitation. Many of the drier winters on record, including the extrema, occurred during neutral winters. During La Niña winters precipitation was not statistically significantly different from that in neutral winters. Winter temperature was not statistically significantly different during El Niño and La Niña winters within the century of record. The results were consistent between separate analyses of data from the 2 different sources.

\section{INTRODUCTION}

The El Niño Southern Oscillation (ENSO) is an atmospheric cycle originating in the central and eastern tropical Pacific Ocean (Diaz and Markgraf 1992; Capotondi et al. 2015; Lindsey 2016). The ENSO oscillates between El Niño and La Niña conditions, which involve changes in sea surface temperature, air temperature, wind circulation, and other sea surface and atmospheric properties. These alter both the Polar and Pacific jet streams, which in turn alter weather patterns around the world, including in North America (Ropelewski and Halpert 1987; Aceituno 1992; Zhang et al. 2011; Yu et al. 2012; Johnson et al. 2013; Yu and Zou 2013; Zhou et al. 2014; Lindsey 2017). In general, the impacts within the United States are during the cold half of the year (Halpert 2014). In affected regions, the resulting anomalies in precipitation and temperature can have societal effects on agriculture, flood control, water supply, and aquatic ecology, etc. (Hansen et al. 2001; Mitra et al. 2014). ENSO phases have variable strengths

${ }^{1}$ Address correspondence to Robert W. Ritzi Jr., Department of Earth and Environmental Sciences, 3640 Colonel Glenn Hwy., Wright State University, Dayton, OH 45430, USA. Email: robert.ritzi@wright.edu
(Wolter and Timlin 1998), and phases with similar strengths can have different effects on continentalscale weather (Arndt 2015).

Continental-scale studies have suggested that ENSO may affect winter temperature and precipitation in the Ohio and Upper Mississippi River Valley, and that the effect is most pronounced during the winter months-generally taken to include November through March (Barnston 2015; Lindsey 2017; Gabric et al. [date unknown]). El Nińo conditions can extend the Pacific jet stream across the North American continent, causing warmer weather with less precipitation during the winter. La Niña conditions can cause the Polar jet stream to dip further south in North America, causing colder weather with increased precipitation during the winter (Zhang etal. 2011; Lindsey 2017; NOAA CPC 2019; NOAA PSL [date unknown a]. Based on data from 1950 to present (Fig. 1), NOAA CPC (2019) indicates that during El Niño winters there is a greater than $80 \%$ probability that the Midwest region (Ohio, Indiana, Michigan,

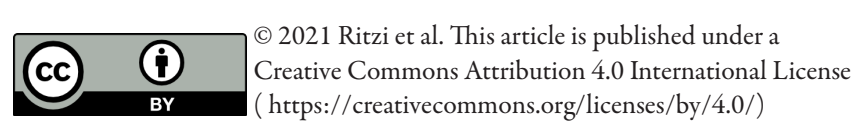


and Illinois) will have on the order of $3 \mathrm{~cm}$ less precipitation. NOAA CPC (2019) also indicate a precipitation increase of the order of $3 \mathrm{~cm}$ with 60 to $80 \%$ probability during La Nińa winters. The NOAA CPC (2019) results are based on data corrected and interpolated onto a $0.25^{\circ}$ latitude $\times$ $0.25^{\circ}$ longitude grid from an irregular nationwide network of stations as described by Xie et al. (2010). Using the CPC data from 1981 to 2014 , Barnston (2015) found a similar precipitation anomaly during El Niño winters. The statistical significance of the anomalies calculated from the sample data and the confidence intervals on the estimates for probability of occurrence were not reported. In a more geographically focused study using data from 1957 to 1990 (8 El Niño winters), Gabric et al. ([date unknown]) found that for the Ohio Valley and Southern Great Lakes region, 87.5\% of El Niño winters on record had less than average precipitation, with an average decrease of $4.6 \mathrm{~cm}$. They also found that $62.5 \%$ of the El Niño years had an increase in temperature, with an average increase of $0.25^{\circ} \mathrm{C}$. The statistical significance of these sample statistics were not reported. La Niña winters were not included in their study.

The interest of the current study is in the localized impact of ENSO on winter precipitation and temperature in southwest Ohio (Fig. 2). The variability in precipitation and temperature in southwest Ohio can be important within the context

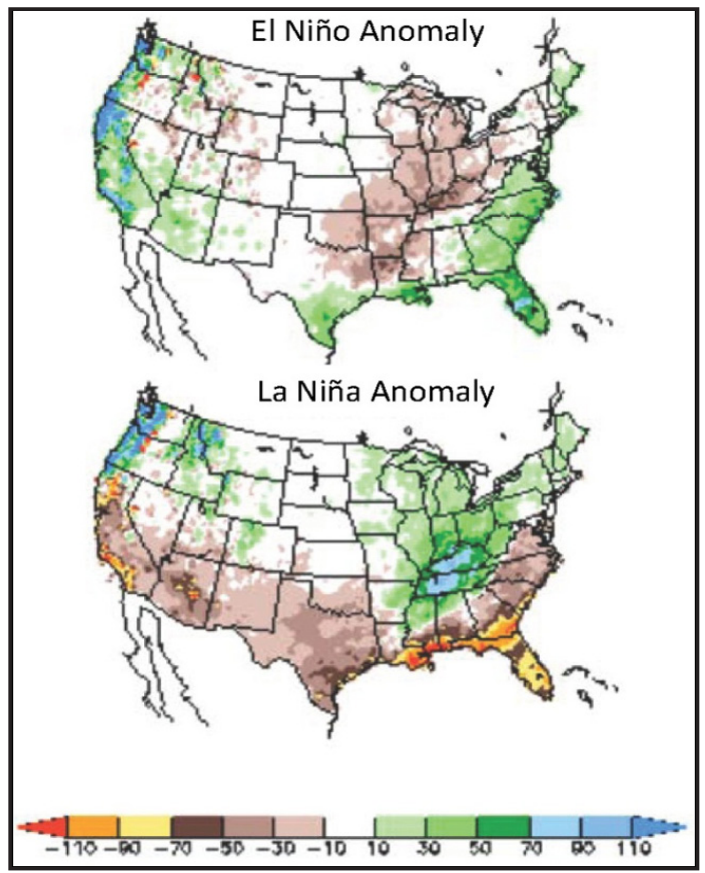

FIGURE 1. Expected precipitation anomalies $(\mathrm{mm})$ in January through March as estimated by NOAA CPC (2019). (Top) El Niño. (Bottom) La Niña. Figure from NOAA CPC (2019). of regional planning, flood control, water quality, and agriculture. Southwest Ohio includes major metropolitan areas (Cincinnati, Dayton) as well as some of the most productive agricultural lands in the Midwest. The metropolitan areas lie along rivers, and historical flooding of those rivers has played a significant role in the history of flood control engineering (Eckert 1981; Becker and Nolan 1988). Variations in precipitation and temperature impact crop production, which is mostly without irrigation. The region includes a number of watersheds (the largest being the Great Miami River watershed) (Fig. 2) which, increasing in scale, are comprised by the Ohio River watershed, the Mississippi River watershed, and ultimately terminate in the Gulf of Mexico. Precipitation and temperature in these watersheds, and their impact on agriculture, have a role in establishing water quality across scales (e.g., nutrients from agricultural runoff in the Midwest create zones of hypoxia in the Gulf of Mexico).

The goal of the current study was to examine historical records available from southwest Ohio (Fig. 2) for the effects of ENSO on winter precipitation and temperature. The historical records for precipitation and temperature span 121 years, longer than in any of the prior studies cited above. In addition to using longer records here, the current study adds an assessment of the statistical significance of anomalies in the sample statistics.

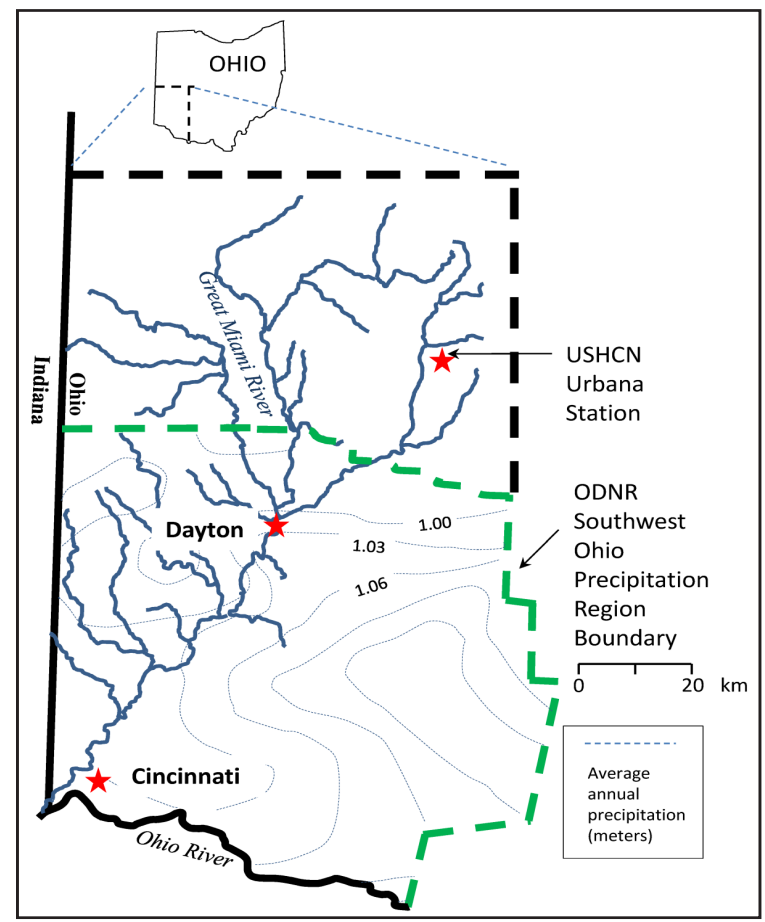

FIGURE 2. Southwest Ohio study area and data locations. Abbreviations used in figure: USHCN, U.S. Historical Climatology Network; ODNR, Ohio Department of Natural Resources. 
Based on the work reviewed above, the current study hypothesizes that winters during El Niño conditions most often had below-average precipitation and above-average temperatures, and that winters during La Niña conditions most often had above-average precipitation and below-average temperature (Table 1). The hypotheses are tested by statistically analyzing historical records of winter precipitation and temperature to determine if there are statistically significant anomalies during ENSO phases that are consistent with the hypotheses.

\section{DATA AND METHODS}

The sample population data are from the 121 winters from 1896 to 2016 (Fig. 3). The data are the measured monthly-total precipitation and the monthly average of daytime high temperatures, published by the U.S. Historical Climatology Network (NOAA NCEI [date unknown a, date unknown b]), hereafter referred to as the USHCN records. The USHCN data were measured at station USH00338552 located near Urbana, Ohio (Fig. 2). The next nearest USHCN station (Kenton) is about

Table 1

Hypotheses for ENSO effects on winter precipitation and temperature in southwest Ohio

\begin{tabular}{lll}
\hline \hline Record & El Niño conditions & La Niña conditions \\
\hline Precipitation & Below average & Above average \\
Temperature & Above average & Below average \\
\hline
\end{tabular}
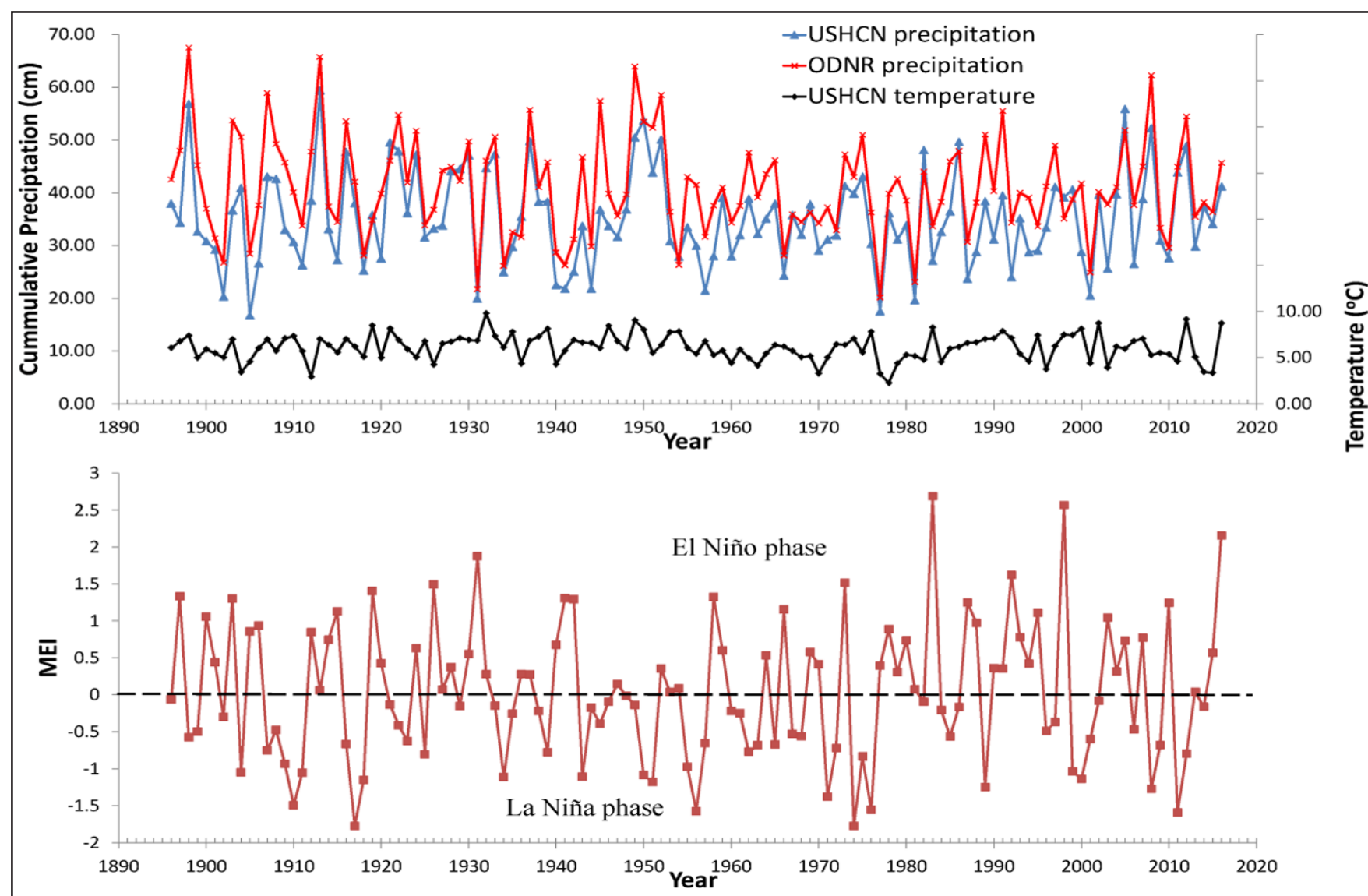

FIGURE 3. Records for winter weather and the extended Multivariate ENSO Index (MEI). Cumulative precipitation is for November through March. Temperature is the average daily high in winter. Abbreviations used in figure: USHCN, U.S. Historical Climatology Network; ODNR, Ohio Department of Natural Resources. 
$100 \mathrm{~km}$ north and across the Gulf of Mexico/ Atlantic Ocean drainage divide. USHCN data have corrections for bias from such factors as changes in the time of observation (Karl et al. 1986), station moves, instrument changes (Karl and Williams 1987; Quayle et al. 1991), and urban bias (Karl et al. 1988).

Another historical record of monthly winter precipitation was analyzed. This second record, covering a period of time corresponding to the USHCN record, was published by the Ohio Department of Natural Resources (ODNR MWIR [date unknown]) and is hereafter referred to as the ODNR record. Each entry in this record is a monthly precipitation total that is spatially averaged from tens of stations located in their Southwest Ohio Precipitation Region, delineated in Fig. 2. The number and location of stations used in the average have varied with time, and the data do not have the adjustments for bias as applied to the USHCN data. The isohyetal contours (ODNR HAO [date unknown]) shown for the Southwest Ohio Precipitation Region in Fig. 2 exhibit only small gradients within the region, as expected given the low topographic relief and modest size of the region. The ODNR record has some limitations, as it is not adjusted for possible biases and is possibly smoothed from spatial averaging. However, it seems representative of the type of record that could be available for other study regions that lack a USHCN station with an adjusted record. Therefore, the current report analyzed the ODNR data to see if any anomalies associated with ENSO, identified in the USHCN data set, can also be consistently identified in the unadjusted and aggregated ODNR record.

The ENSO cycle is represented in the analyses by the extended Multivariate ENSO Index, MEI (Wolter 2011). The MEI is determined from sea level pressure, zonal and meridional components of the surface wind, sea surface temperature, surface air temperature, and cloudiness using data from the International Comprehensive Ocean Atmosphere Data Set (Wolter 2018). The MEI is increasingly positive with the strength of the El Niño phase and increasingly negative with the strength of the La Niña phase. The extended MEI was chosen (among possible ENSO indices) because it has been computed for the century-long time frame corresponding to the precipitation and temperature records (Fig. 3).

Because ENSO cycles differ in their strength, coverage, and seasonality, there is subjectivity in what constitutes an ENSO "event." According to the NOAA Physical Sciences Laboratory (PSL), however, there are "broad agreements," and NOAA PSL ([date unknown a]) identified El Niño and La Niña events that occurred from 1896 to 2016 (hereafter referred to as El Niño and La Niña winters). These are listed in Table 2 along with "neutral" (non-event) winters. Some of the analyses below are of the data subdivided into the 3 subpopulations shown in Table 2 .

Table 2

Years with ENSO winters defined by NOAA PSL ${ }^{a}$

\begin{tabular}{|c|c|c|c|c|c|c|c|c|c|}
\hline \multicolumn{10}{|c|}{ El Niño } \\
\hline 1897 & 1900 & 1903 & 1906 & 1915 & 1919 & 1926 & 1931 & 1941 & 1942 \\
\hline 1958 & 1966 & 1973 & 1978 & 1980 & 1983 & 1987 & 1988 & 1992 & 1995 \\
\hline 1998 & 2003 & 2007 & 2010 & 2016 & & & & & \\
\hline \multicolumn{10}{|c|}{ Neutral } \\
\hline 1896 & 1898-1899 & 1901-1902 & 1905 & $1907-1908$ & $1912-1914$ & 1916 & $1920-1924$ & $1927-1930$ & $1932-1933$ \\
\hline $1935-1938$ & 1940 & 1944-1949 & $1952-1954$ & 1957 & 1959-1961 & $1963-1965$ & $1967-1970$ & 1972 & 1975 \\
\hline 1977 & 1979 & 1981-1982 & 1984-1986 & 1990-1991 & 1993-1994 & 1996-1997 & 2001-2002 & 2004-2006 & 2009 \\
\hline \multicolumn{10}{|l|}{$2013-2015$} \\
\hline \multicolumn{10}{|c|}{ La Niña } \\
\hline 1904 & 1909 & 1910 & 1911 & 1917 & 1918 & 1925 & 1934 & 1939 & 1943 \\
\hline 1950 & 1951 & 1955 & 1956 & 1962 & 1971 & 1974 & 1976 & 1989 & 1999 \\
\hline 2000 & 2008 & 2011 & 2012 & & & & & & \\
\hline
\end{tabular}

${ }^{a}$ Based on the strength of the MEI index (NOAA PSL [date unknown a]). Years are referenced to January. 
Winter is taken to be the 5 months from November to March, consistent with NOAA PSL ([date unknown b]) and Gabric et al. ([date unknown]). Prior studies have used various metrics including the 5-month winter-mean (NOAA PSL [date unknown b]; Gabric et al. [date unknown]) and a shorter 3-month mean (NOAA CPC 2019). Here, 4 metrics were used for winter precipitation and 3 were used for winter temperature (Table 3). The precipitation metrics include (a) the cumulative-total winter precipitation and (b) the 5-month winter-mean precipitation; these metrics might show seasonal-scale anomalies due to ENSO effects. The other 2 precipitation metrics are (c) the maximum-month precipitation (i.e., the value for the month with the highest value within each season) and (d) the minimum-month precipitation; these metrics might show shorter (1 month) scale anomalies that might not be identified with the season-long metrics. The temperature metrics included the mean monthly, the maximum-month, and the minimum-month winter temperature. Summary statistics for these metrics are listed in Table 3.

Fig. 4 a shows, for example, the cumulative winter precipitation metric plotted after subdividing the data into the subpopulations of El Niño winters, La Niña winters, and neutral winters. The winters with the greatest and the least precipitation occur in neutral years, and ENSO phases do not appear to contribute any more than neutral years to the overall variation in precipitation. Note that there is no strong visual indication of a non-stationary mean or variance within each data subpopulation. Fig. 4b shows the mean monthly temperature metric utilizing the same 3 subpopulations; it has the same characteristics as Fig. 4a and similarly does not indicate that ENSO phases contribute any more than neutral years to the overall variation. This is also true for plots of all of the other metrics.

Table 3

Summary statistics for metrics on winter precipitation and temperature ${ }^{\text {a }}$

\begin{tabular}{|c|c|c|c|c|c|c|c|c|}
\hline \multicolumn{9}{|c|}{ Winter precipitation $(\mathrm{cm})$} \\
\hline \multirow[b]{2}{*}{ USHCN data } & \multicolumn{2}{|c|}{ All winters } & \multicolumn{2}{|c|}{ El Niño winters } & \multicolumn{2}{|c|}{ Neutral winters } & \multicolumn{2}{|c|}{ La Niña winters } \\
\hline & Mean & Std. dev. & Mean & Std. dev. & Mean & Std. dev. & Mean & Std. dev. \\
\hline Cumulative & 35.16 & 8.88 & 30.40 & 6.10 & 36.35 & 9.43 & 36.52 & 7.87 \\
\hline Mean monthly & 7.03 & 1.78 & 6.08 & 1.22 & 7.27 & 1.89 & 7.30 & 1.57 \\
\hline Maximum-month & 11.53 & 4.62 & 9.57 & 2.32 & 12.31 & 5.02 & 11.53 & 4.31 \\
\hline Minimum-month & 3.20 & 1.55 & 2.68 & 1.34 & 3.27 & 1.55 & 3.54 & 1.64 \\
\hline \multicolumn{9}{|l|}{ ODNR data } \\
\hline Cumulative & 41.02 & 9.36 & 36.65 & 7.24 & 41.76 & 9.96 & 43.34 & 8.49 \\
\hline Mean monthly & 8.20 & 1.87 & 7.33 & 1.45 & 8.35 & 1.99 & 8.67 & 1.70 \\
\hline Maximum-month & 13.13 & 4.64 & 11.26 & 2.83 & 13.69 & 5.11 & 13.59 & 4.19 \\
\hline Minimum-month & 3.93 & 1.60 & 3.43 & 1.50 & 4.00 & 1.59 & 4.23 & 1.70 \\
\hline \multicolumn{9}{|c|}{ Winter temperature $\left({ }^{\circ} \mathrm{C}\right)$} \\
\hline & \multicolumn{2}{|c|}{ All winters } & \multicolumn{2}{|c|}{ El Niño winters } & \multicolumn{2}{|c|}{ Neutral winters } & \multicolumn{2}{|c|}{ La Niña winters } \\
\hline USHCN data & Mean & Std. dev. & Mean & Std. dev. & Mean & Std. dev. & Mean & Std. dev. \\
\hline Mean monthly & 6.12 & 1.43 & 6.30 & 1.41 & 5.96 & 1.43 & 6.42 & 1.34 \\
\hline Maximum-month & 11.68 & 2.06 & 11.92 & 1.39 & 11.50 & 2.19 & 11.95 & 2.17 \\
\hline Minimum-month & 1.10 & 2.40 & 1.33 & 2.02 & 0.89 & 2.56 & 1.48 & 2.18 \\
\hline
\end{tabular}

a Includes 121 winters: 25 El Niño, 24 La Niña, and 72 neutral. 


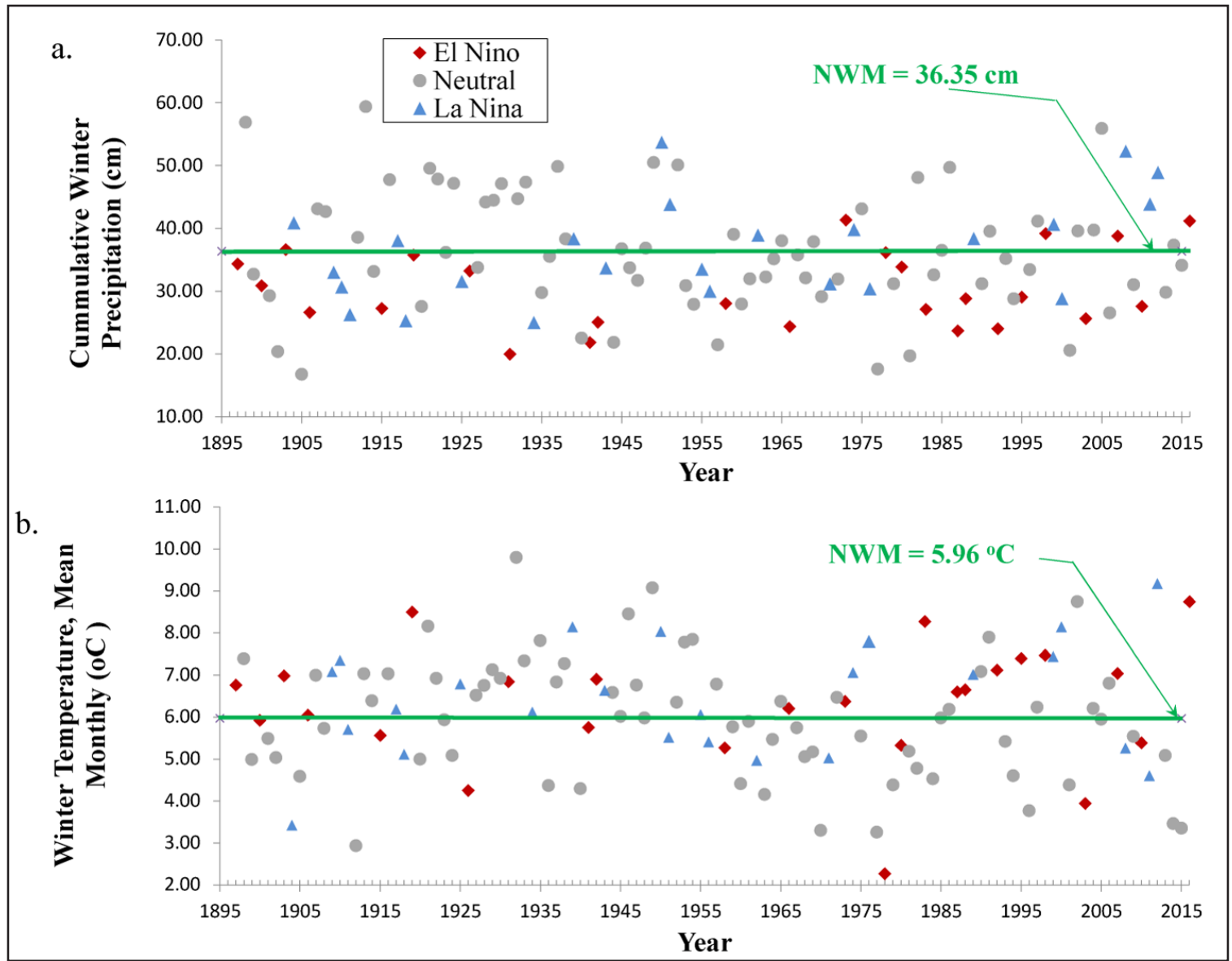

FIGURE 4. USHCN records divided into El Niño winter, La Niña winter, and neutral winter subpopulations. (a) Cumulative winter precipitation. (b) Mean monthly winter temperature (daily highs). Green horizontal line is the neutral-winter mean (NWM).

Three statistical methods were used to test the hypotheses. Two of the methods used the data subdivided into 3 subpopulations defined as El Niño winters, La Niña winters, and neutral winters, consistent with previous studies (Gabric et al. [date unknown]; NOAA CPC 2019). The first method quantified the proportion of El Niño or La Niña winters in which a metric fell above or below the mean of all neutral winters. The second method used an independent-samples $t$-test comparison of the mean value of a metric for all El Niño or La Niña winters against the mean of all neutral winters; this method tests whether or not the means are statistically significantly different. The third method was not based on the trinary categorization of the ENSO cycle; instead, the effect of the continuous cycle of ENSO conditions was considered by analyzing the variations in precipitation and temperature metrics as a function of the extended MEI, using linear regression.

The $t$-tests and regression analyses assume normality of error terms and constant variance. These assumptions were assessed via residual plots and deemed to be satisfied for all metrics except the maximum-month precipitation. The maximummonth precipitation data were skewed, and the model assumptions were met by using a natural $\log$ transformation in the $t$-tests and regression for that metric. Each of these methods is described in the remainder of this section.

Note that studies such as Mitra et al. (2014) have used spectral methods to define the frequency of ENSO phases and the attenuation and phase lag in the response of hydrometeorologic processes. Such methods are relevant if there is uncertainty over when an ENSO phase occurred and if a multi-year lag is expected in the response (such as might be true with the piezometric surface in aquifers with significant storage). In the current study the years of ENSO winters are known, and any effects on precipitation and temperature are expected to occur within the winter of those years. Questions on the spectral frequency at which ENSO phases occurred and evaluation of the phase lag in hydrometeorologic responses are outside of the scope of this article, and thus spectral decomposition was not employed. 


\section{Proportion of El Niño or La Niña Winters with Temperature or Precipitation Above or Below the Neutral-winter Mean}

The sample proportion of El Niño and La Niña winters in which a metric fell above or below the neutral-winter mean (NWM) were calculated to give an estimate of the proportion of El Niño and La Niña winters in which the metric was, relative to the NWM, consistent with the hypotheses above. For example, a result supportive of the El Niño hypothesis would be that the sample proportion of El Niño winters that had cumulative precipitation less than the NWM, and the 95\% confidence interval (CI), all fall above 0.5 . A result supportive of the La Niña hypothesis would be that the sample proportion of La Niña winters with cumulative precipitation greater than the NWM, and the $95 \% \mathrm{CI}$, are all above 0.5 . All confidence intervals were calculated via the Wilson score interval methodology (Wilson 1927).

\section{Independent Samples t-test Comparison of the Mean Winter Values}

Statistical tests for difference in the means should be constructed with a null hypothesis $\left(\mathrm{H}_{0}\right)$ that is hoped to be rejected. Here the $\mathrm{H}_{0}$ states that the mean during El Niño or La Nińa winters is the same as the NWM. Rejection of $\mathrm{H}_{0}$ was defined to be a probability of error (Type I) less than 0.05 in one-tailed tests (Walpole and Myers 1972). Rejection of $\mathrm{H}_{0}$ supports the alternative hypotheses $\left(\mathrm{H}_{1}\right)$. For example, in considering cumulative precipitation in El Niño winters, $\mathrm{H}_{1}$ states that the mean was less than the NWM. For La Niña winters, $\mathrm{H}_{1}$ states that the mean was greater than the NWM.

\section{Linear Regression}

An example of a result consistent with the research hypotheses would be a regression model for cumulative precipitation vs. MEI that is statistically significant (taken as a $p$-value less than or equal to $0.05)$ and has a negative slope. An $R^{2}$ value above 0.25 indicates that MEI explains a meaningful proportion of the variance in precipitation (Cohen 1988), and a value below 0.25 would not support the conclusion that MEI is a significant control on the variance.

\section{RESULTS \\ Results from Analyses of ENSO Winters}

Precipitation in El Niño winters. The sample proportion of El Niño winters that had precipitation metrics below the NWM in the USHCN record is given in Table 4, along with the $95 \%$ CI. OfEl Niño winters, $80 \%$ had cumulative winter precipitation less than the NWM; this result is consistent with Fig. 4a. Also, 80\% had mean monthly precipitation less than the NWM, $92 \%$ had less precipitation than the NWM in the maximum-month of a winter, and $72 \%$ had less precipitation than the NWM in the minimummonth of a winter. The $95 \%$ CI on the sample proportions listed in Table 4 fall entirely above 0.5 , and thus these results are unambiguously consistent with the research hypothesis that El Niño winters have had less precipitation. The results from the ODNR sample population are similar, except that the $95 \%$ CI for minimum-month precipitation is not entirely above 0.5 .

The results of the statistical tests for difference in the means are listed in Table 5. In the USHCN record, the mean cumulative precipitation in El Niño winters was $5.96 \mathrm{~cm}$ less than the NWM, and the monthly average was $1.19 \mathrm{~cm}$ less. These anomalies are statistically significant with $p$-values of $3.5 \mathrm{E}-04$. The anomalies for the maximum-month and minimum-month precipitation metrics are also statistically significant ( $p=2.5 \mathrm{E}-05, p=0.04$, respectively). The results are similar for the ODNR record, except the $p$-value for the minimum-month precipitation is slightly above 0.05 .

Collectively, these results show that El Niño winters in southwest Ohio have most often had less precipitation than neutral winters, with an average of 5 to $6 \mathrm{~cm}$ less per 5 month winter season, or about $1 \mathrm{~cm}$ less per month on average. The month that had the most precipitation in a season had about $3 \mathrm{~cm}$ less on average than neutral winters. These results were consistent between the USHCN and ODNR records. The month that had least precipitation during a winter season had $0.6 \mathrm{~cm}$ less in the USHCN record, a small but statistically significant anomaly. The result from the ODNR record for this metric is consistent but is equivocal with respect to its statistical significance. 
Table 4

Proportion of El Niño and La Niña winters with mean above or below the neutralwinter mean (NWM) ${ }^{\text {a }}$. The $95 \%$ confidence intervals $(\mathrm{Cl})$ are given in parentheses.

Winter precipitation

\begin{tabular}{llll}
\hline \multirow{2}{*}{ USHCN data } & $\begin{array}{c}\text { Proportion of El Niño winters } \\
\text { below the NWM }\end{array}$ & & $\begin{array}{c}\text { Proportion of La Niña winters } \\
\text { above the NWM }^{\mathrm{b}}\end{array}$ \\
\cline { 2 - 2 } $\begin{array}{l}\text { Cumulative } \\
\text { Mean monthly }\end{array}$ & $0.80(0.61,0.91)$ & & $0.50(0.31,0.69)$ \\
Maximum-month & $0.80(0.61,0.91)$ & $0.50(0.31,0.69)$ \\
Minimum-month & $0.92(0.75,0.98)$ & $0.25(0.12,0.45)$ \\
& $0.72(0.52,0.86)$ & $0.42(0.25,0.61)$
\end{tabular}

Proportion of La Niña winters

\begin{tabular}{ll}
\hline ODNR data & \\
\hline Cumulative & $0.80(0.61,0.91)$ \\
Mean monthly & $0.80(0.61,0.91)$ \\
Maximum-month & $0.88(0.70,0.96)$ \\
Minimum-month & $0.68(0.48,0.83)$
\end{tabular}

$0.58(0.39,0.76)$

$0.58(0.39,0.76)$

$0.33(0.18,0.53)$

$0.50(0.31,0.69)$

Winter temperature

\begin{tabular}{llll}
\hline USHCN data & \multicolumn{1}{c}{$\begin{array}{c}\text { Proportion of El Niño winters } \\
\text { above the NWM }\end{array}$} & & $\begin{array}{c}\text { Proportion of La Niña winters } \\
\text { below the NWM }{ }^{\mathrm{b}}\end{array}$ \\
$\begin{array}{l}\text { Mean monthly } \\
\text { Maximum-month }\end{array}$ & $0.64(0.45,0.82)$ & & $0.38(0.22,0.57)$ \\
Minimum-month & $0.6(0.4,0.79)$ & & $0.50(0.31,0.69)$ \\
\hline
\end{tabular}

a Includes 121 winters: 25 El Niño, 24 La Niña, and 72 neutral.

${ }^{\mathrm{b}}$ Highlighted values color key: Green, proportion and confidence interval all above $50 \%$.

Yellow, proportion above $50 \%$ but not the $95 \%$ CI. Red, proportion not above $50 \%$.

Precipitation in La Niña winters. In both the USHCN and ODNR records, for all the metrics, the proportion of the La Niña winters with precipitation above the NWM and the low end of the $95 \%$ CI were not above 0.5 (Table 4). In the results of the statistical tests for difference in the means, listed in Table 5 , the $p$-values are all well above 0.05 , and thus none of the anomalies in $\mathrm{La}$ Niña winters are statistically significant. The results for all the precipitation metrics, collectively, do not support the hypothesis that La Niña winters more often had above average precipitation.

Temperature in El Niño winters. The sample proportion of El Niño winters that had temperature metrics above the NWM in the USHCN record is given in Table 4. The values are above 0.5 for the mean monthly, the maximum-month, and the minimum-month metrics. However, the low end of the $95 \%$ CI was above 0.5 only for the minimum-month metric. The anomalies listed in Table 5 are positive for all the temperature metrics, consistent with the hypothesis. However, $p$-values in all cases are above 0.05 and so the differences are not statistically significant. The null hypothesis of zero difference in mean temperature during El Niño winters cannot be rejected for any metric. Thus, the results do not collectively support the hypothesis that El Niño winters were warmer on average.

Temperature in La Niña winters. The sample proportion of La Niña winters that had temperature metrics below the NWM in the USHCN record is given in Table 4. The results are not above 0.5 for any of the metrics. The results in Table 5 show all the mean temperature metrics were above the 
Table 5

Results from hypothesis testing on differences in the mean with unknown and unequal variances

Precipitation: El Niño

\begin{tabular}{|c|c|c|c|c|c|}
\hline USHCN data & $\begin{array}{l}\text { Anomaly (difference } \\
\text { from NWM) }(\mathrm{cm})\end{array}$ & $\begin{array}{l}\text { Null } \\
\text { hypothesis }\end{array}$ & $\begin{array}{l}\text { Alternate } \\
\text { hypothesis }\end{array}$ & Result $^{a}$ & $p$-value \\
\hline Cumulative & $\overline{-5.96}$ & $\overline{\text { Equals NWM }}$ & $\overline{<N W M}$ & $\overline{\text { Reject null }}$ & $3.5 \mathrm{E}-04$ \\
\hline Mean monthly & -1.19 & Equals NWM & $<$ NWM & Reject null & $3.5 \mathrm{E}-04$ \\
\hline Maximum-month & $-2.74^{b}$ & Equals NWM & $<\mathrm{NWM}$ & Reject null & $2.5 \mathrm{E}-05$ \\
\hline Minimum-month & -0.59 & Equals NWM & $<$ NWM & Reject null & 0.040 \\
\hline \multicolumn{6}{|l|}{ ODNR data } \\
\hline Cumulative & -5.12 & Equals NWM & $<$ NWM & Reject null & 0.004 \\
\hline Mean monthly & -1.02 & Equals NWM & $<$ NWM & Reject null & 0.004 \\
\hline Maximum-month & $-2.44^{\mathrm{b}}$ & Equals NWM & $<\mathrm{NWM}$ & Reject null & 0.001 \\
\hline Minimum-month & -0.57 & Equals NWM & $<$ NWM & Cannot reject null & 0.056 \\
\hline
\end{tabular}

Precipitation: La Niña

\begin{tabular}{|c|c|c|c|c|c|}
\hline USHCN data & $\begin{array}{l}\text { Anomaly (difference } \\
\text { from NWM) }(\mathrm{cm})\end{array}$ & $\begin{array}{l}\text { Null } \\
\text { hypothesis }\end{array}$ & $\begin{array}{l}\text { Alternate } \\
\text { hypothesis }\end{array}$ & Result $^{a}$ & $p$-value \\
\hline Cumulative & 0.17 & $\overline{\text { Equals NWM }}$ & $>>\mathrm{NWM}$ & Cannot reject null & 0.466 \\
\hline Mean monthly & 0.03 & Equals NWM & $>$ NWM & Cannot reject null & 0.466 \\
\hline Maximum-month & $-0.78^{b}$ & Equals NWM & >NWM & Cannot reject null & 0.171 \\
\hline Minimum-month & 0.27 & Equals NWM & >NWM & Cannot reject null & 0.248 \\
\hline \multicolumn{6}{|l|}{ ODNR data } \\
\hline Cumulative & 1.58 & Equals NWM & $>$ NWM & Cannot reject null & 0.227 \\
\hline Mean monthly & 0.32 & Equals NWM & $>$ NWM & Cannot reject null & 0.227 \\
\hline Maximum-month & $-0.10^{\mathbf{b}}$ & Equals NWM & $>$ NWM & Cannot reject null & 0.372 \\
\hline Minimum-month & 0.23 & Equals NWM & >NWM & Cannot reject null & 0.283 \\
\hline
\end{tabular}

Temperature: El Niño

\begin{tabular}{|c|c|c|c|c|c|}
\hline USHCN data & $\begin{array}{l}\text { Anomaly (difference } \\
\text { from NWM) }\left({ }^{\circ} \mathrm{C}\right)\end{array}$ & $\begin{array}{l}\text { Null } \\
\text { hypothesis }\end{array}$ & $\begin{array}{l}\text { Alternate } \\
\text { hypothesis }\end{array}$ & Result $^{a}$ & $p$-value \\
\hline Mean monthly & 0.34 & Equals NWM & $\overline{>N W M}$ & Cannot reject null & 0.160 \\
\hline Maximum-month & 0.42 & Equals NWM & >NWM & Cannot reject null & 0.142 \\
\hline Minimum-month & 0.44 & Equals NWM & >NWM & Cannot reject null & 0.198 \\
\hline
\end{tabular}

Temperature: La Niña

\begin{tabular}{|c|c|c|c|c|c|}
\hline USHCN data & $\begin{array}{l}\text { Anomaly (difference } \\
\text { from NWM) }\left({ }^{\circ} \mathrm{C}\right)\end{array}$ & $\begin{array}{l}\text { Null } \\
\text { hypothesis }\end{array}$ & $\begin{array}{l}\text { Alternate } \\
\text { hypothesis }\end{array}$ & Result $^{a}$ & $p$-value \\
\hline$\overline{\text { Mean monthly }}$ & 0.45 & $\overline{\text { Equals NWM }}$ & $\overline{<\mathrm{NWM}}$ & Cannot reject null & 0.086 \\
\hline Maximum-month & 0.45 & Equals NWM & $<$ NWM & Cannot reject null & 0.199 \\
\hline Minimum-month & 0.59 & Equals NWM & $<\mathrm{NWM}$ & Cannot reject null & 0.145 \\
\hline
\end{tabular}

${ }^{a}$ Highlighted values color key: Green, reject the null hypothesis with $p$-value less than 0.05 . Yellow, cannot reject the null hypothesis at the 0.05 level but $p$-value is close. Red, cannot reject the null hypothesis.

${ }^{\mathrm{b}}$ The hypothesis test used the natural-log transform and the anomaly is stated as the difference in the geometric means. 
NWM. Thus, the hypothesis that La Niña winters are more often cooler is contraindicated by the sample proportions and means. Furthermore, the $95 \%$ CI on estimates of proportion all span the threshold of 0.5 , and the differences in the means from neutral winters all have $p$-values above 0.05 . Therefore, statistically significant anomalies (positive or negative) in the metrics are not present. These results do not support the hypothesis that La Nińa winters were more often cooler with mean temperature below the NWM.

\section{Regression Analyses of Winter Precipitation and Temperature as a Function of the MEI}

A regression of cumulative winter precipitation as a function of MEI, using the USHCN record, is shown in Fig. 5a. The slope of the model is negative, consistent with the research hypothesis, and gives a mean decrease of $1.9 \mathrm{~cm}$ in winter per unit increase in the MEI (a decrease of $0.38 \mathrm{~cm}$ in mean monthly precipitation). Table 6 shows that the $p$-values for the cumulative winter precipitation and the mean monthly precipitation metrics are both less than 0.05 , a result also consistent with the hypothesis.

Table 6 shows the results of the regression analyses of the other precipitation metrics, for both data sets. The slopes for all the precipitation metrics using either data record are negative and thus consistent with the hypothesis. The $p$-value for the $\ln$ (maximum-month) and the minimum-month metrics are less than 0.05 for the ODNR record, but not for the USHCN record though it is close for the $\ln$ (maximum-month) metric.

The results from both records, for both the cumulative and the mean monthly winter precipitation, indicate that under stronger El Nińo conditions winters have had less precipitation. However, the adjusted $R^{2}$ values for the results with all metrics, using either record, range from 0.05 to much smaller values (all well below 0.25 ). Thus, these models account for a very small amount of the overall variability in winter precipitation, and the results do not support MEI being a significant control on the variance.

The results of the regression analysis of the winter temperature metrics as a function of MEI are also listed in Table 6. Fig. 5b shows one example for mean monthly temperature. In all cases the slopes are negative, which is inconsistent with the hypothesis. In all cases the magnitudes of the slopes are negligible, the $p$-values greatly exceed 0.05 , and the adjusted $R^{2}$ values are negligible. These results do not support the hypothesis that past winter temperatures were affected by ENSO, and do not support the specific hypotheses that El Niño winters have been warmer and La Niña winters have been colder in this region.

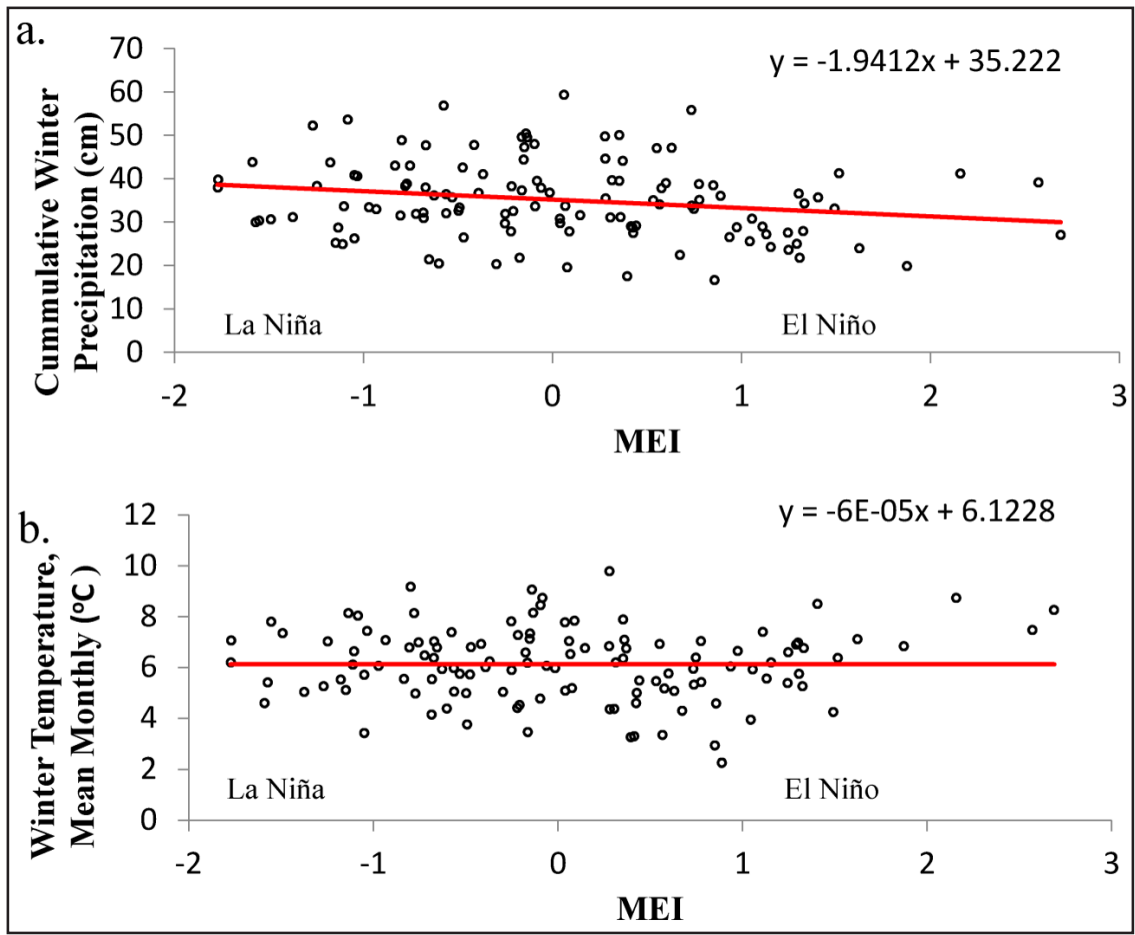

FIGURE 5. Examples of linear regression for (a) cumulative winter precipitation and (b) mean monthly winter temperature (daily highs) vs. the extended Multivariate ENSO Index (MEI) 
Table 6

Results from linear regression ${ }^{a}$

\begin{tabular}{|c|c|c|c|}
\hline \multicolumn{4}{|c|}{ Winter precipitation $(\mathrm{cm})$} \\
\hline USHCN data & Slope & $p$-value & Adjusted $R^{2}$ \\
\hline Cumulative & -1.94115 & 0.025658 & 0.033087 \\
\hline Mean monthly & -0.38823 & 0.025658 & 0.033087 \\
\hline $\ln ($ maximum-month) & -0.06129 & 0.054971 & 0.022455 \\
\hline Minimum-month & -0.18779 & 0.220535 & 0.004288 \\
\hline \multicolumn{4}{|l|}{ ODNR data } \\
\hline Cumulative & -2.46393 & 0.006946 & 0.051736 \\
\hline Mean monthly & -0.49279 & 0.006946 & 0.051736 \\
\hline $\ln ($ maximum-month) & -0.06158 & 0.040065 & 0.026835 \\
\hline Minimum-month & -0.31319 & 0.045867 & 0.024955 \\
\hline \multicolumn{4}{|c|}{ Winter temperature $\left({ }^{\circ} \mathrm{C}\right)$} \\
\hline USHCN data & Slope & $p$-value & Adjusted $R^{2}$ \\
\hline Mean monthly & $\overline{-6.5 \mathrm{E}-05}$ & $\overline{0.999633}$ & $<1 \mathrm{E}-9$ \\
\hline Maximum-month & -0.07855 & 0.699445 & $<1 \mathrm{E}-3$ \\
\hline Minimum-month & -0.05143 & 0.828637 & $<1 \mathrm{E}-4$ \\
\hline
\end{tabular}

${ }^{a}$ Highlighted values color key: Green, slope is consistent with hypotheses or $p$-value is less than 0.05 . Yellow, $p$-value is close to 0.05 but slightly above. Red, slope is inconsistent with hypotheses or $p$-value is greater than 0.05 or adjusted $R^{2}$ value is less than 0.25 .

\section{DISCUSSION AND SUMMARY EI Niño Winters have Commonly had Less Precipitation}

The century-long historical records in southwest Ohio support the hypothesis that El Niño winters have more often had less precipitation. The record indicates an $80 \%$ probability $(+11 \%,-19 \%)$ of lower precipitation in the winter months of November through March. Mean monthly precipitation in those months was on the order of a centimeter lower than the mean in neutral winters. Cumulative winter precipitation was on average $5 \mathrm{~cm}$ lower. These results are generally consistent with those of Gabric et al. ([date unknown]) and NOAA CPC (2019), and are consistent with the research hypothesis. Furthermore, while the prior studies had identified an anomaly in mean precipitation during El Niño winters, it was shown in the current study (with a longer data record) that the anomaly is statistically significant beyond the $p=0.05$ level. Stronger El Niño conditions produced drier winters, with $2 \mathrm{~cm}$ less precipitation per unit increase in the MEI metric for El Niño strength. Variation in the MEI, however, only explains about $3 \%$ of the overall variability in winter precipitation. Many of the drier winters, including the driest on record, have occurred in neutral years. Therefore, while an El Nińo condition was an indicator for a drier than average winter, variations in winter precipitation were large-with very dry conditions in neutral winters.

\section{The Record Does Not Support that El Niño Winters have been Warmer}

The historical record does not support the hypothesis that El Niño winters were warmer than average. Although more than half of the El Niño winters had a temperature above the neutral-winter 
mean, the $95 \%$ CI on the proportion statistics are not above 0.5 for the majority of the temperature metrics. Importantly, for any of the 3 metrics, the difference in the mean temperature between El Niño and neutral years was not statistically significant. Regression analyses do not show a significant relationship between winter temperature and MEI.

\section{The Record Does Not Support that La Niña Winters have been Cooler with More Precipitation}

The historical record does not support the hypothesis that La Niña conditions have affected winter precipitation or temperature. The results of the analysis of proportions of winters where the temperature metrics fell above or below the neutral-winter mean were ambiguous. Also, the mean differences in precipitation and temperature from the neutral-winter mean were not statistically significant.

\section{Relationship of these Results to those from Prior Studies}

The results of the current study represent the southwest Ohio region only, and should not be taken to represent the broader region of Ohio or the Midwest. For example, winter weather in northern Ohio is strongly influenced by Lake Erie; an analysis of data from this region, such as included in Gabric et al. ([date unknown]), may show different relationships to ENSO phenomena. Indeed, studies at a local scale complement broader studies at the regional or continental scale. For example, the difference in conclusions between the current study and the broader studies by Gabric et al. ([date unknown]) and NOAA CPC (2019) may indicate that southwest Ohio comprises a relatively neutral area lying between regions, to the north and south, that are more strongly impacted by ENSO cycles.

Alternatively, the differences in results may simply arise from the longer data record used in the current study, or from the requirement that differences must be statistically significant to be accepted. Local-region studies should be encouraged, especially if there are more extensive data records available that allow for reducing the uncertainty in sample statistics within the context of estimation and testing the hypotheses about anomalies. Ultimately, these additional studies could be useful in characterizing the influence of ENSO, if existent, on more local hydrometeorological processes.

The results of analyses using the USHCN record and the ODNR record for precipitation were generally consistent. The El Niño anomaly could still be identified in the ODNR record, despite that record being spatially averaged and lacking the adjustments for bias applied to the USHCN record. This provides optimism for the success of similar local studies in other regions that lack a nearby USHCN station and have only unadjusted records to analyze.

\section{Relationship of these Results to Societal Concerns}

These results indicate that as the ENSO cycle in the eastern Pacific trends toward an El Niño condition, less winter precipitation can be anticipated in southwest Ohio. This result was previously indicated by NOAA CPC (2019) for the larger Midwest. The confirmation here, using local data and with an assessment of the statistical significance of the anomaly, adds weight to this conclusion. This knowledge is societally relevant when considering activities that might be affected by deficits in winter precipitation, such as agriculture and outdoor winter recreation. Farmers might plan for drier soil conditions at the start of spring planting season. Alpine skiing venues might plan for additional snowmaking.

These results do not indicate that La Niña winters should be colder with more precipitation in southwest Ohio. The development of a La Nińa phase should therefore not engender concern, such as about a higher probability for increased spring runoff and associated flood risk. For example, in anticipating the development of a La Nińa condition in late fall of 2017, one Dayton, Ohio, meteorologist reported "if we are indeed entering a La Niña pattern, then we can expect a wet winter" (Elwell 2017). Such a forecast is contraindicated by our analysis of the historical record for the local region. Furthermore, we found no indication that El Niño or La Niña conditions in the eastern Pacific should be used to forecast warmer or colder winters in southwest Ohio. 


\section{Conclusions}

Records over the last century of winter precipitation and temperature in southwest Ohio support the hypothesis that El Niño conditions, occurring in the eastern Pacific, decrease winter precipitation in the southwest Ohio region. Eighty percent of El Niño winters had below-average winter precipitation. The average anomaly in precipitation for the winter season (November through March) was of the order of $-5 \mathrm{~cm}$, and the average anomaly in the driest month of winter was of the order of $-3 \mathrm{~cm}$. Precipitation decreased with the increase in the MEI measure of El Niño strength. These results were statistically significant beyond the $p=0.05$ level. However, departures from average were large in neutral winters, and El Niño winters only explain about $3 \%$ of the variance in winter precipitation. Many of the driest winters, including the driest on record, have occurred in neutral winters. Therefore, while the El Niño condition has been associated with drier winters, variations in winter precipitation were large and very dry winters have occurred independent of El Niño conditions. The historical records do not support the hypothesis that winter precipitation has been statistically significantly different from neutral winters during La Niña conditions. The historical records, furthermore, do not support the hypothesis that winter temperature has been statistically significantly different during El Niño or La Niña winters relative to neutral winters.

\section{ACKNOWLEDGEMENTS}

Scott Kirk of the Ohio Department of Natural Resources (ODNR) provided valuable assistance in obtaining aggregated hydrometeorologic data from the ODNR Water Inventory Reports. Klaus Wolter of the National Oceanic and Atmospheric Administration (NOAA) provided valuable assistance in interpreting data provided through the NOAA MEI website. David Dominic improved the wording of this article. This research did not receive any specific grant from funding agencies in the public, commercial, or not-for-profit sectors.

\section{LITERATURE CITED}

Aceituno P. 1992. El Niño, the southern oscillation, and ENSO: confusing names for a complex ocean-atmosphere interaction. B Am Meteorol Soc. 73(4):483-485. https://doi.org/10.1175/1520-0477-73.4.483

Arndt D. 2015. Not what I ordered: how El Niño is like a bad bartender [NOAA blog]. Beyond the data: a blog by the nation's official climate record keepers. [accessed 2021 Feb 18].

https://www.climate.gov/news-features/blogs/beyond-data/ not-what-i-ordered-how-el-nino-bad-bartender

Barnston A. 2015. Do recent global precipitation anomalies resemble those of El Niño? [NOAA blog]. ENSO blog: a blog about monitoring and forecasting El Niño, La Niña, and their impacts. [accessed on 2021 Feb 18].

https://www.climate.gov/news-features/blogs/enso/dorecent-global-precipitation-anomalies-resemble-those-el-nino

Becker CM, Nolan PB. 1988. Keeping the promise: a pictorial history of the Miami Conservancy District. Dayton $(\mathrm{OH})$ : Landfall Press. 208 p. ISBN 13: 9780913428665.

Capotondi A, Wittenberg AT, Newman M, Di Lorenzo E, Yu JY, Braconnot P, Cole J, Dewitte B, Giese B, Guilyardi E, Jin FF. 2015. Understanding ENSO diversity. B Am Meteorol Soc. 96(6):921-938.

https://doi.org/10.1175/BAMS-D-13-00117.1

Cohen J. 1988. Statistical power analyses for the behavioral sciences. 2nd ed. Hillsdale (NJ): Lawrence Erlbaum Associates. 400 p. ISBN 13: 9780805802832.

Diaz HF, Markgraf V, editors. 1992. El Niño: historical and paleoclimatic aspects of the Southern Oscillation. New York (NY): Cambridge University Press. 476 p. ISBN 10: 9780521430425.

Eckert AW. 1981. A time of terror: the great Dayton flood. Dayton $(\mathrm{OH})$ : Landfall Press. 342 p. ISBN 13: 9780913428023.

Elwell E. 2017 Oct 10. Mild fall may be sign of La Niña. Dayton Daily News $[\mathrm{OH}]$. Contributing article by the WHIO Storm Center 7 chief meteorologist.

Gabric L, Keeney HJ, Pytlak ES. [date unknown]. Climatological effects of the El Niño-Southern Oscillation in the lower Great Lakes and Ohio Valley [NOAA online article]. NOAA, National Weather Service, Cleveland $(\mathrm{OH})$ Weather Forecast Office: El Niño \& the Lower Great Lakes and Ohio Valley. [accessed 2021 Feb 18]. http://www.weather.gov/cle/research_ENSO_GtLakes

Halpert M. 2014. United States El Niño impacts [NOAA blog]. ENSO blog: a blog about monitoring and forecasting El Niño, La Niña, and their impacts. [accessed on 2021 Feb 18]. https:/www.climate.gov/news-features/blogs/enso/unitedstates-el-nino-impacts-0?page $=1$

Hansen JW, Jones JW, Irmak A, Royce F. 2001. El Niño-Southern Oscillation impacts on crop production in the southeast United States. In: Rosenzweig C, coordinating editor. Impacts of El Niño and climate variability on agriculture. Madison (WI): American Society of Agronomy, Crop Science Society of America, and Soil Science Society of America. p. 55-76. ASA Special Publication No. 63, Chapter 4. https://doi.org/10.2134/asaspecpub63.ch4 
Johnson NT, Martinez CJ, Kiker GA, Leitman S. 2013. Pacific and Atlantic sea surface temperature influences on streamflow in the Apalachicola-Chattahoochee-Flint river basin. J Hydrol. 489:160-179. https://doi.org/10.1016/j.jhydrol.2013.03.005

Karl TR, Williams CN Jr, Young PJ, Wendland WM. 1986. A model to estimate the time of observation bias associated with monthly mean maximum, minimum and mean temperature for the United States. J Clim Appl Meteorol. 25(2):145-160.

https://doi.org/10.1175/1520-0450(1986)025<0145:AMTETT>2.0.CO;2

Karl TR, Williams CN Jr. 1987. An approach to adjusting climatological time series for discontinuous inhomogeneities. J Clim Appl Meteorol. 26(12):1744-1763.

https://doi.org/10.1175/1520-0450(1987)026<1744:AATACT>2.0.CO;2

Karl TR, Diaz HF, Kukla G. 1988. Urbanization: its detection and effect in the United States climate record. J Climate. 1(11):1099-1123.

https://doi.org/10.1175/1520-0442(1988)001<1099:UIDAEI>2.0.CO;2

Lindsey R. 2016. Climate variability: oceanic Niño index [NOAA news \& feature article]. [accessed 2021 Feb 18]. https://www.climate.gov/news-features/understandingclimate/climate-variability-oceanic-nino-index

Lindsey R. 2017. How El Niño and La Niña affect the winter jet stream and U.S. climate [NOAA news \& feature article]. [accessed 2021 Feb 18].

https://www.climate.gov/news-features/featured-images/howel-nino-and-la-nina-affect-winter-jet-stream-and-us-climate

Mitra S, Srivastava P, Singh S, Yates D. 2014. Effect of ENSOinduced climate variability on groundwater levels in the lower Apalachicola-Chattahoochee-Flint River Basin. T ASABE. 57(5):1393-1403.

https://doi.org/10.13031/trans.57.10748

[NOAA CPC] NOAA Climate Prediction Center. 2019. ENSO temperature \& prediction composites [NOAA online data page]. [accessed 2021 Feb 18].

https:/www.cpc.ncep.noaa.gov/products/precip/CWlink/ ENSO/composites/EC_ENP_index.shtml

[NOAA NCEI] NOAA National Centers for Environmental Information. [date unknown a]. Climate Data Online (CDO) [NOAA online database]. [accessed 2021 Feb 18]. https://www.ncdc.noaa.gov/cdo-web/

[NOAA NCEI] NOAA National Centers for Environmental Information. [date unknown b]. U.S. Historical Climatology Network (USHCN) [NOAA online database]. [accessed 2021 Feb 18].

https://www.ncdc.noaa.gov/data-access/land-based-station-data/ land-based-datasets/us-historical-climatology-network-ushen

[NOAA PSL] NOAA Physical Sciences Laboratory. [date unknown a]. El Niño Southern Oscillation (ENSO), Past Events [NOAA online animations]. [accessed 2021 Feb 18]. https://psl.noaa.gov/enso/ [select past events tab]

[NOAA PSL] NOAA Physical Sciences Laboratory. [date unknown b]. ENSO response comparison plots [NOAA online data visualization]. [accessed 2021 Oct 22]. https://psl.noaa.gov/enso/compare/
[ODNR HAO] Ohio Department of Natural Resources. [date unknown]. Hydrologic Atlas for Ohio [online map product]. Columbus (OH): Ohio Department of Natural Resources, Division of Geological Survey, Groundwater Resources Group. [accessed 2021 Feb 18].

https://ohiodnr.gov/wps/portal/gov/odnr/discover-and-learn/safety-conservation/ about-ODNR/geologic-survey/groundwater-resources/hydrologic-atlas

[ODNR MWIR] Ohio Department of Natural Resources. [date unknown]. Monthly Water Inventory Report for Ohio [online database]. Columbus $(\mathrm{OH})$ : Ohio Department of Natural Resources, Division of Geological Survey, Groundwater Resources Group. [accessed 2021 Feb 18]. [The entire data record was provided to the authors by S. Kirk, ODNR]. Available as monthly publications online at:

https://ohiodnr.gov/wps/portal/gov/odnr/discover-and-learn/safety-conservation/ about-ODNR/geologic-survey/groundwater-resources/water-inventory-report

Quayle RG, Easterling DR, Karl TR, Hughes PY. 1991. Effects of recent thermometer changes in the Cooperative Station Network. B Am Meteorol Soc. 72(11):1718-1723.

https://doi.org/10.1175/1520-0477(1991)072<1718:EORTCI>2.0.CO;2

Ropelewski CF, Halpert MS. 1987. Global and regional scale precipitation patterns associated with the El Niño/Southern Oscillation. Mon Weather Rev. 115(8):1606-1626.

https://doi.org/10.1175/1520-0493(1987)115<1606:GARSPP>2.0.CO;2

Walpole RE, Myers RH. 1972. Probability and statistics for engineers and scientists. New York (NY): Macmillan. ISBN 13: 9780029799109.

Wilson EB. 1927. Probable inference, the law of succession, and statistical inference. J Am Stat Assoc. 22(158):209-212. https://doi.org/10.1080/01621459.1927.10502953

Wolter K, Timlin MS. 1998. Measuring the strength of ENSO events: how does 1997/98 rank? Weather. 53(9):315-324. https://doi.org/10.1002/j.1477-8696.1998.tb06408.x

Wolter K. 2011. Extended Multivariate ENSO Index (MEI. ext) [NOAA webpage]. Boulder (CO): NOAA Physical Sciences Laboratory (PSL). [accessed 2021 Feb 18]. https://psl.noaa.gov/enso/mei.ext/

Wolter K. 2018. Multivariate ENSO Index (MEI) [NOAA webpage]. Boulder (CO): NOAA Physical Sciences Laboratory (PSL). https://psl.noaa.gov/enso/mei.old/mei.html

Yu JY, Zou Y, Kim ST, Lee T. 2012. The changing impact of El Niño on US winter temperatures. Geophys Res Lett. 39(15): L15702. 8 p. https://doi.org/10.1029/2012GL052483

Yu JY, Zou Y. 2013. The enhanced drying effect of Central-Pacific El Niño on US winter. Environ Res Lett. 8(1):014019. 7 p. https://doi.org/10.1088/1748-9326/8/1/014019

Zhang T, Hoerling MP, Perlwitz J, Sun DZ, Murray D. 2011. Physics of U.S. surface temperature response to ENSO. J Climate. 24(18):4874-4887. https://doi.org/10.1175/2011JCLI3944.1

Zhou ZQ, Xie SP, Zheng XT, Liu Q, Wang H. 2014. Global warming-induced changes in El Niño teleconnections over the North Pacific and North America. J Climate. 27(24):9050-9064. https://doi.org/10.1175/JCLI-D-14-00254.1 